\title{
Okul Öncesi Öğretmen Adaylarının Öğretmenlik Mesleğine Yönelik Tutumlarının Farklı Değişkenler Açısından İncelenmesi"
}

\author{
Hikmet Doğrul ${ }^{1 *}$, Figen Kılıç² \\ Mersin Üniversitesi Eğitim Programları ve Öğretim Anabilim Dalı \\ ORCID: H. Doğrul (0000-0002-0514-2505), F. Kılıç (0000-0002-2546-2549)
}

\begin{abstract}
Özet
$\mathrm{Bu}$ araștırmanın amacı okul öncesi öğretmen adaylarının öğretmenlik mesleğini tercih etmelerine neden olan faktörlerin ve öğretmenlik mesleğine yönelik tutumlarının incelenmesidir. Araştırmada betimsel yöntem tarama modeli kullanılmıștır. Araştırmanın çalıșma grubunu 2016-2017 Eğitim-Öğretim yılında Mersin Üniversitesi Eğitim Fakültesi Okul Öncesi Öğretmenliği Ana Bilim Dalı́nda eğitim gören 170 öğretmen adayı olușturmaktadır. Veri toplama aracı olarak Aşkar ve Erden (1987) tarafından geliștirilen "Öğretmenlik Mesleğine Yönelik Tutum Ölçeği" kullanılmıștır. Okul öncesi öğretmen adaylarının, öğretmenlik mesleğine yönelik tutumlarının çok yüksek olduğu tespit edilmiștir. Öğretmenlik mesleğine ilişkin tutum puanlarının; cinsiyet, yaşadıkları yer, sınıf düzeyleri, tercih sıraları, mezun oldukları lise türü ve ailelerinde öğretmen bulunma durumuna göre anlamlı bir farklılık göstermediği görülmekteyken; tercihlere etki eden faktörler, tercihlere etki eden kişiler, alandan memnuniyet durumuna göre anlamlı bir farklılık gösterdiği sonucunu ortaya koymuştur.
\end{abstract}

Anahtar Kelimeler: öğretmen adayı, öğretmenliğe yönelik tutum, okul öncesi eğitim

\section{Investigation of Pre-School Teacher's Attitudes Towards Teaching Rofession in Terms of Different Variables}

\begin{abstract}
The purpose of this research is the investigation of the factors that cause pre-service teachers to prefer teaching profession and the attitudes towards teaching profession. The descriptive research method survey model was used in this study. The study group of the research consists of 170 candidate teachers studying in Mersin University, Faculty of Education, Department of Pre-school Education in 2016-2017 academic year. "Attitude Scale towards Teaching Profession" developed by Aşkar and Erden (1987) was used as a data collection tool. It has been determined that the attitudes of pre-school teachers are very high towards teaching profession. While attitude scores regarding teaching profession don't show a significant difference according to gender, the place where they live, class levels, order of prefence, the type of high school they graduated from and the presence of teachers in their families; attitude scores regarding teaching profession Show a significant difference according to factors affecting preferences, people affecting preferences, satisfaction about the field.
\end{abstract}

Keywords: candidate teacher, attitude towards teaching, pre-school education

\section{Giriș}

Okul öncesi dönem; bireyin doğumdan zorunlu eğitim sürecine başlayıncaya dek olan zaman aralığını kapsamakta olup; bireyin ilköğretim basamağı eğitim ve öğretim faaliyetlerine hazırlı süreciyle kazanılacak bilgi, beceri ve davranışların şekillenmesi; ilgi, yetenek, beceri, tutum ve alışkanlıkların fiziksel, sosyal ve bilişsel zekânın

*Yazışma Adresi / Address for Correspondence:

H. Doğrul, Email: hikmet_dogrul@hotmail.com

Geliş Tarihi / Received Date: 05.03.2020

Kabul Tarihi / Accepted Date: 12.04.2020

Doi: $10.26701 /$ uad.699452 gelişmesiyle gelecekteki kişiliğinin temelini oluşturmasına hazırlık dönemi olması sebebiyle yaşamın en kritik dönemlerinden biridir.

Bireylerin doğumdan sonra ebeveyn ve birincil sosyal çevre ile geçirdiği dönemden sonra farklı bir sosyal etkileşim ve yaşantı sürecine girdikleri ilk yer okul öncesi kurumları ve aldıkları ilk eğitim okul öncesi eğitimidir. Okul öncesi eğitim; çocukları gelecekteki eğitim süreçlerine hazırlaması ve bilişsel, duyuşsal, devinimsel özelliklere dair becerilerin gelişiminin temelini oluşturması sebebiyle çok büyük önem taşımaktadır (Razon, 1987). Okul öncesi eğitimi almış olarak ilkokula başlayan ço- 
cukların, bu eğitimi görmeyenlere oranla daha katılımcı, girişken ve uyumlu olduğu araştırmalar tarafından ortaya konmuștur (Erbay, 2008; Esaspehlivan, 2006; Oktay, 2000; Oktay, 2005; Pehlivan, 2006; Toluç, 2008; Yeşil, 2008). $\mathrm{Bu}$ bağlamda okul öncesi dönemindeki eğitim-öğretim sürecini etkili bir şekilde kılavuzlayan, çocuklara aile dışında ilk kez rehberlik eden ve onlarla iyi iletişim kurabilme yetisine sahip okul öncesi öğretmenlerine ihtiyaç duyulmaktadır. Dolayısıyla okul öncesi öğretmenlerinden bu niteliklere sahip olmaları beklenmektedir (Köksal Akyol ve Koçer Çiftçibaşı, 2005; Poyraz ve Dere, 2001). $\mathrm{Bu}$ niteliklerin kazanılması ve öğretmenlik mesleğine yönelik tutum, nitelikli öğretmen yetiştirmeyi kendisine görev edinmiş olan yükseköğretim kurumlarının eğitim fakültelerinde alınan eğitimle sağlanmaktadır.

Öğretmen yetiştirmede en önemli unsurlardan birisi de nitelikli meslek elemanlarının nasıl yetiştirileceği konusudur. $\mathrm{Bu}$ noktada öğretmenlik mesleğine aday öğrencilerin nitelikleri, mesleğe uygunlukları ön plana çıkmaktadır (Adıgüzel, 1998). Öğretmenlik mesleğini tercih eden öğrencilerin sosyo-kültürel, akademik, psikolojik faktörlerin, öğretmenlik mesleğine yönelik tutumlarını oluşturan etkenler olduğu düşünülmekte ve bu faktörlerin öğretmenlik mesleğine yönelik tutumlarına etkisini değerlendirmeye yönelik pek çok araştırmanın gerçekleştirildiği ve bu araştırmalarda ortaya çıkan sonuçlara göre öğretmenlerin mesleğe yönelik tutumlarının onların nasıl bir öğretmen olacağı konusunda anahtar rol oynadığını ileri sürmektedir (Erdem, Gezer ve Çokadar, 2005; Seferoğlu, 2004). Bu bağlamda, okul öncesi öğretmeninin de kişilik özellikleri ve öğretmenlik mesleğine yönelik tutumları önem kazanmaktadır (Argun ve İkiz, 2003). Çünkü okul öncesi eğitim kurumlarında öğretmenleriyle uzun süre vakit geçiren çocuklar, süreç içerisinde öğretmenlerinin tutum ve davranışlarını gözlemler, model alır ve taklit eder. Dolayısıyla çocuklar öğretmenlerinin kişiliğini benimser. Bir mesleğe dair sahip olunan tutumlar, kişinin o meslekte başarılı olabilmesini etkileyen unsurlardan biridir (Gürbüz ve Kışoğlu, 2007; Johnson \& Howell, 2005).

Alan yazında yapılan incelemelerde öğretmen adaylarının öğretmenlik mesleğine yönelik tutumlarının farklı değişkenler açısından incelenmesine yönelik birçok çalışmanın olduğu gözlemlenmektedir (Alkan, 2018; Ambusaidi ve Farai, 2017; Balc1, 2017; Çetin, 2017; Garmon, 2004; Keskin, 2017; Krecic ve Grmek; 2005; Shippen, Crites, Houchins, Ramsey, Simon, 2005; Şahin ve Şahin,2017; Tuncer ve Dikmen, 2018; Uyanık, 2017; Yaylak, 2019; Yıldız, Saygi, 2017).

Literatür taraması sonucunda incelenen araştırmalarda öğretmen adaylarının öğretmenlik mesleğine yönelik tutumlarının incelendiği birçok çalışma olmasına rağmen özellikle son on yılda okul öncesi öğretmen adaylarının öğretmenlik mesleğine yönelik tutumlarına ilişkin çalışmalarda bir boşluk olduğu görülmekte ve bu alanda çok sayıda çalışmaya rastlanmamaktadır. Dolayısıyla yapılan bu çalışmanın alanda bir boşluğu doldurması beklenmektedir.

Okul öncesi eğitim, özellikle, 20. yüzyllın son çeyreğinden itibaren günümüzde gelişmiş toplumların eğitim sistemlerinin vazgeçilmez bir parçası haline gelmektedir. İnsan yaşamında böylesine önemli bir yeri olan bu yılların en iyi biçimde değerlendirilmesi, nitelikli bir okul öncesi eğitimle gerçekleşebilir. Bu nedenle, okul öncesi eğitimin niteliğini artırmak, en etkili biçimde düzenlemek, tüm yaş grubuna hizmet edecek biçimde yaygınlaştırmak ve bu eğitimi verecek öğretmenlerin mesleğe karşı olumlu tutum sahibi olmaları çok önemlidir. Bu çalışmada okul öncesi öğretmen adaylarının öğretmenlik mesleğine karşı tutumlarını farklı değişkenlere göre incelenmesi ve elde edilen sonuçlar doğrultusunda önerilerde bulunulması önemli görülmüştür.

Bu çalışmanın amacı, Mersin Üniversitesi Eğitim Fakültesi Temel Eğitimi Bölümü Okul Öncesi Öğretmenliği Anabilim Dalı́nda eğitim gören okul öncesi öğretmeni adaylarının Okul öncesi öğretmen adaylarının öğretmenlik mesleki tercihlerini etkileyen etmenler ile çeşitli değişkenlere göre öğretmenlik mesleğine karşı tutumlarını değerlendirmektir.

\subsection{Araştırmanın Problemi ve Alt Problemleri}

Araştırmanın problemi 'Okul öncesi öğretmen adaylarının öğretmenlik mesleki tercihlerini etkileyen etmenler ile çeşitli değişkenlere göre öğretmenlik mesleğine karşı tutumları nasıldır?" olarak belirlenmiştir. Araştırmanın alt problemleri ise;

- Okul öncesi öğretmen adaylarının öğretmenlik mesleki tercihlerini etkileyen etmenler nelerdir?

- Okul öncesi öğretmen adaylarının öğretmenlik mesleğine yönelik tutumları nasıldır?

- Okul öncesi öğretmen adaylarının öğretmenlik mesleğine yönelik tutum puanları çeşitli değişkenlere göre farklllık göstermekte midir?

\section{YÖNTEM}

$\mathrm{Bu}$ araştırma betimsel yöntem kullanılarak tarama modelinde nicel veriler toplanarak gerçekleştirilmiş̧ir. Tarama modeli, geçmişte ya da halen var olan bir durumu var olduğu şekliyle betimlemeyi amaçlayan araştırma yaklaşımıdır (Karasar, 2012). Tarama modeli, geniş gruplar üzerinde yürütülen, bireylerin bir olay ya da olgu hakkındaki görüşlerinin, tutumlarının belirlendiği olay ya da olguların betimlemesine dayalı olarak yapılan çalıșmaları kapsamaktadır (Karakaya, 2011).

\section{1. Çalışma Grubu}

Yapılan araştırmanın çalışma grubunu 2016-2017 Eğitim-Öğretim yılında Mersin Üniversitesi Eğitim Fakültesi Temel Eğitimi Bölümü Okul Öncesi Öğretmenliği Ana Bilim Dalı'nda eğitim gören 170 öğretmen adayı oluşturmaktadır. 
Tablo 1. Okul öncesi öğretmen adaylarının demografik özelliklere göre dağıımı (N=170)

\begin{tabular}{|c|c|c|c|c|c|c|}
\hline \multirow{4}{*}{$\begin{array}{l}\text { 1.Cinsiyet } \\
\text { 2.Sınıf }\end{array}$} & \multicolumn{2}{|l|}{ ERKEK } & \multicolumn{4}{|l|}{ KADIN } \\
\hline & \multicolumn{2}{|l|}{$31(\% 18,2)$} & \multicolumn{4}{|l|}{$139(\% 81,8)$} \\
\hline & Lisans 1 & Lisans 2 & Lisans 3 & \multicolumn{3}{|l|}{ Lisans 4} \\
\hline & $42(\% 24,7)$ & $48(\% 28,2)$ & $41(\% 24,1)$ & \multicolumn{3}{|l|}{$39(\% 22,9)$} \\
\hline \multirow{2}{*}{ 3.Alandan Memnuniyet } & Evet & Kısmen & \multicolumn{4}{|l|}{ Hayır } \\
\hline & $127(\% 74,7)$ & $36(\% 21,2)$ & \multicolumn{4}{|l|}{$7(\% 4,1)$} \\
\hline \multirow{2}{*}{ 4.íkamet Edilen Yer } & \multicolumn{3}{|c|}{ KENTSEL BÖLGE } & \multicolumn{3}{|c|}{ KIRSAL BÖLGE } \\
\hline & \multicolumn{3}{|l|}{$129(\% 75,9)$} & \multicolumn{3}{|l|}{$41(\% 24,1)$} \\
\hline \multirow{2}{*}{ 5.Mezun Olunan Lise Türü } & Düz Lise & Anadolu Lisesi & Meslek Lisesi & & Anadolu Öğretmen Lisesi & Diğer \\
\hline & $20(\% 11,8)$ & $85(\% 50)$ & $29(\% 17,1)$ & & $31(\% 18,2)$ & $5(\% 2,9)$ \\
\hline \multirow{2}{*}{ 6.Baba Mesleği } & Memur & isşçi & Serbest Meslek & Esnaf & Diğer & Hayatta Değil \\
\hline & $39(\% 22,9)$ & $39(\% 22,9)$ & $32(\% 18,8)$ & $22(\% 12,9)$ & $27(\% 15,9)$ & $11(\% 6,5)$ \\
\hline
\end{tabular}

Aşağıda Tablo 1'de okul öncesi öğretmen adaylarının kişisel özelliklerine yönelik elde edilen bulgular gösterilmiştir.

Tablo 1 incelendiğinde 170 okul öncesi öğretmen adayının; cinsiyetlere göre incelediğimizde 139'unun kadın öğretmen adayı $(\% 81,8)$, 31'inin erkek öğretmen adayı $(\% 18,2)$ olduğu; sınıf düzeylerine göre incelediğimizde 1.sınıfta 42 öğretmen adayı (\%24,7), 2.sınıfta 48 öğretmen adayı (\%28,2), 3.sınıfta 41 öğretmen adayı (\%24,1), 4.sınıfta 39 öğretmen adayı $(\% 22,9)$ olduğu; alandan memnuniyet durumlarına göre incelediğimizde memnun olan 127 öğretmen adayı $(\% 74,7)$, kısmen memnun olan 36 öğretmen adayı $(\% 21,2)$, memnun olmayan 7 öğretmen adayı $(\% 4,1)$ olduğu; ikamet ettikleri yere göre incelediğimizde kentsel bölgede 129 öğretmen adayı $(\% 75,9)$, kırsal bölgede 41 öğretmen adayı $(\% 24,1)$ olduğu; mezun oldukları lise türüne göre incelediğimizde Anadolu Lisesi mezunu olan 85 öğretmen adayı (\%50), Anadolu Öğretmen Lisesi mezunu olan 31 öğretmen adayı ( \%18,2), Meslek Lisesi mezunu olan 29 öğretmen adayı (\%17,1), Düz Lise mezunu olan 20 öğretmen adayı (\%11,8), Diğer türdeki liselerden mezun olan 5 öğretmen adayı $(\% 2,9)$ olduğu bulgularına ulaşılmıştır.

Baba mesleklerine göre incelediğimizde, baba mesleği Memur olan 39 öğretmen adayı (\%22,9), İşçi olan 39 öğretmen adayı $(\% 22,9)$, Serbest Meslek olan 32 öğretmen adayı $(\% 18,8)$, diğer meslek gruplarında olan 27 öğretmen adayı (\%15,9), Esnaf olan 22 öğretmen adayı (\%12,9), babası hayatta olmayan 11 öğretmen adayı $(\% 6,5)$ olduğu tespit edilmiştir.

\subsection{Veri Toplama Araçları}

Araştırmada Bilgi Formu ve Öğretmenlik Mesleğine Yönelik Tutum Ölçeği olmak üzere 2 adet veri toplama aracı kullanılmıştır.

\subsubsection{Bilgi Formu}

Öğretmen adaylarının hem kişisel hem de öğretmenlik mesleğini seçmelerinde etkisi olduğu düşünülen özellikleri belirlemek amacıyla araştırmacı ve alan uzmanları tarafından hazırlanan kişisel bilgi formundan oluşmaktadır. Bilgi formu hazırlandıktan sonra alanında uzman 2 öğretim üyesi ve alan uzmanı öğretmenlerden görüş alınarak son şekli verilmiştir. Bilgi formunda, öğretmen adaylarına yönelik kişisel bilgileri toplamak için toplam 14 soru yer almaktadır.

\subsection{2. Öğretmenlik Mesleğine Yönelik Tutum Ölçeği}

Aşkar ve Erden (1987) tarafından geliştirilen bu ölçek 34 maddeden oluşmakta ve 5'li Likert tipine uygun olarak puanlanmaktadır. Ölçek 10'u olumsuz, 24'ü olumlu olmak üzere toplam 34 sorudan oluşmaktadır. Ölçeğin güvenirlik katsayısı 0,96 olarak bulunmuştur. Bu çalışmada ise 0,953 olarak belirlenmiştir. Ölçekte sorulara verilen cevap seçenekleri Kesinlikle Katılıyorum”, "Katılıyorum”, "Kararsızım”, “Katılmıyorum” ve "Kesinlikle Katılmıyorum” olmak üzere 5'li Likert tipinde derecelendirilmiştir. Öğretmen adaylarının olumlu maddelere verdikleri cevaplar kesinlikle katılıyorum (5), katılıyorum (4), kararsızım (3), katılmıyorum (2), kesinlikle katılmıyorum (1) olacak şekilde 5'den 1'e doğru olacak şekilde puanlandırılarak SPSS programında analiz edilmiştir.

\subsection{Verilerin Analizi}

Verilerin analizinde öğretmen adaylarının öğretmenlik mesleğine ilişkin tutumlarını belirlemek amacıyla betimsel analiz (descriptive statistics) uygulanmıştır. Öğretmen adaylarının kişisel özelliklerini belirlemek amacıyla frekans ve yüzdeler, aritmetik ortalama, standart sapma uygulanmıştır. Öğretmen adaylarının öğretmenlik mesleğine ilişkin tutum puanlarını çeşitli değişkenlere göre incelemek amacıyla bağımsız iki örneklem grubu için " $t$ " testi, ikiden çok bağımsız örneklem grubu için tek yönlü varyans analizi ve anlamlı farkı yaratan örneklem gruplarını belirlemek amacıyla Asgari Önemli Fark (LSD) tekniği kullanılmıştır. Sonuçların yorumlanmasında 0,05 anlamlılık düzeyi temel alınmıştır. Araştırma kapsamında istatistikî işlemler için SPSS 20 paket programı kullanılmiştır.

\subsubsection{Nicel Veriler}

Araştırmada kayıp veri analizi sonucunda kayıp veri olmadığı tespit edilmiştir. Öğretmenlik mesleğine ilişkin tutum ölçeğiyle elden edilen bulgularda 7 gözlemin uç değer verdiği gözlenmiştir. İlgili gözlemler analiz dışı bırakılarak uç değer ve normallik incelemesi tekrarlanmıştır. Kolmogorov smirnov normallik test sonuçlarına bakıldığında, dağılımın normal olmadığı görülmektedir (K-S=0,000; p>0,05 ). Bu yüzden basıklık ve çarpıklık kat- 
Tablo 2. Okul öncesi öğretmen adaylarının öğretmenlik mesleki tercihlerini etkileyen etmenler

\begin{tabular}{|c|c|c|c|c|c|}
\hline \multirow{2}{*}{ 1.Alan Tercih Sırası } & $1-5$ & $6-10$ & $11-15$ & $16-20$ & 21 ve üstü \\
\hline & $114(\% 67,1)$ & $28(\% 16,5)$ & $15(\% 8,8)$ & $5(\% 2,9)$ & $8(\% 4,7)$ \\
\hline \multirow{2}{*}{$\begin{array}{l}\text { 2.Alan Tercihlerine } \\
\text { Etki Eden Faktörler }\end{array}$} & $\begin{array}{c}\text { Alana İlgi Duydu- } \\
\text { ğum İçin }\end{array}$ & $\begin{array}{l}\text { Atanma İhtimali } \\
\text { Fazla Olduğu İçin }\end{array}$ & Meslek Sahibi Olmak İçin & Ailem İstediği İçin & Diğer Nedenler \\
\hline & $54(\% 31,8)$ & $47(\% 27,6)$ & $43(\% 25,3)$ & $9(\% 5,3)$ & $17(\% 10)$ \\
\hline \multirow{2}{*}{$\begin{array}{l}\text { 3.Alan Tercihlerinde } \\
\text { Etkisi Bulunan Kişiler }\end{array}$} & Kendi İsteğim & Ailem & Rehber Öğretmen & \multicolumn{2}{|c|}{ Diğer } \\
\hline & $112(\% 65,9)$ & $29(\% 17,1)$ & $18(\% 10,6)$ & \multicolumn{2}{|c|}{$11(\% 6,5)$} \\
\hline \multirow{2}{*}{$\begin{array}{l}\text { 4.Ailede Öğretmen } \\
\text { Bulunma Durumu }\end{array}$} & Anne & Baba & Kardeş & Diğer & Yok \\
\hline & $6(\% 3,5)$ & $9(\% 5,3)$ & $24(\% 14,1)$ & $68(\% 40)$ & $63(\% 37,1)$ \\
\hline
\end{tabular}

sayılarının standart hatalarına oranlanması sonucu elde edilen değerlere (Skewness $=-0,751 ;$ Kurtosis $=-0,242$ ) bakılmıştır. Değerler, -1,96 ile $+1,96$ arasında olduğundan, dağılımın normal olduğu ve uç değer bulunmadığ gözlenmiştir. Elde edilen bu değerlere dayanarak; verilerin homojen olarak dağıldığı ve parametrik testlere uygun olduğu söylenebilir.

Araştırmada kullanılan ölçekten alınabilecek en yüksek (170) ve en düşük (34) puan farkı seçenek sayısına bölünerek bulunmuştur. Bulunan bu sayı seçenekleri temsil eden en alt sayıdan itibaren ilave edilerek verilerin çözümlemesinden elde edilen sonuçlar;

• “34-60 : Hiç Katılmıyorum - Çok Düşük” ,

• “61-87 : Katılmıyorum - Düşük”,

- “88-114 : Kararsizim - Orta”,

• “115-141 : Katılıyorum- Yüksek”,

- “142-170 : Tamamen Katılıyorum- Çok Yüksek” şeklinde yorumlanmıştır.

\subsection{BULGULAR}

\subsection{Alt probleme ilişkin bulgular}

Araştırmanın birinci alt problemi "Okul öncesi öğretmen adaylarının öğretmenlik mesleki tercihlerini etkileyen etmenler nelerdir?" şeklindedir.

Aşağıda Tablo 2'de okul öncesi öğretmen adaylarının öğretmenlik mesleki tercihlerini etkileyen etmenlere dair elde edilen bulgular verilmiştir.

Tablo 2 incelendiğinde 170 okul öncesi öğretmen adayının alan tercih sırasına göre alan tercih sırasını 1-5 arasında yapan 114 öğretmen adayı $(\% 67,1)$ olduğu; alan tercihlerine etki eden faktörlere göre alana ilgi duyduğu için tercih eden 54 öğretmen adayı $(\% 31,8)$ olduğu; alan tercihlerinde etkisi bulunan kişilere göre kendi isteğiyle tercihini yapan 112 öğretmen adayı $(\% 65,9)$ olduğu; ailede öğretmen bulunma durumuna göre 68 öğretmen adayı (\%40), olduğu bulgularına ulaşılmıştır.

\subsection{Alt probleme ilişkin bulgular}

Alt problem: Okul öncesi öğretmen adaylarının öğretmenlik mesleğine yönelik tutumları nasıldır?

Yukarıda ifade edilen alt problemi analiz etmek amacıyla bilgi formundan elde edilen verilere tutum puanlarını elde etmeye yönelik olarak betimsel analiz (descriptive statistics) uygulanmıştır.

Aşağıda Tablo 3'de gösterilmiştir okul öncesi öğretmen adaylarının öğretmenlik mesleğine yönelik tutum düzeylerine ilişkin elde edilen bulgular verilmiştir.

Tablo 3.Okul öncesi öğretmen adaylarının öğretmenlik mesleğine yönelik tutum düzeyleri

\begin{tabular}{|c|c|c|c|c|c|}
\hline & N & $\begin{array}{c}\text { En düşük } \\
\text { puan }\end{array}$ & $\begin{array}{c}\text { En yüksek } \\
\text { puan }\end{array}$ & $\mathbf{X}$ & ss \\
\hline $\begin{array}{c}\text { Okul öncesi } \\
\text { öğretmeni adayları }\end{array}$ & 170 & 94,00 & 170,00 & 143,52 & 1,507 \\
\hline
\end{tabular}

Tablo 3 incelendiğinde, ölçekten alınan en düşük puanın 94, en yüksek puanın 170 ve katılımcıların okul öncesi öğretmen adaylarının öğretmenlik mesleğine yönelik tutum toplam puan ortalamasının X=143,52 olduğu bulgusuna ulaşılmıştır.

\subsection{Alt probleme ilişkin bulgular}

Alt problem: Okul öncesi öğretmen adaylarının öğretmenlik mesleğine yönelik tutum puanları çeşitli değişkenlere göre farklılık göstermekte midir?

Yukarıda ifade edilen alt problemi analiz etmek amacıyla bağımsız iki örneklem grubu için t-testi (independent samples t-test); ikiden çok bağımsız örneklem grubu için tek yönlü varyans analizi (one-way anova) yapılmıştır. Aşağıda Tablo 4'te okul öncesi öğretmen adaylarının öğretmenlik mesleğine yönelik tutumları ile cinsiyet arasındaki farka ilişkin t testi analiz sonuçlarına ilişkin elde edilen bulgular verilmiştir.

Tablo 4. Okul öncesi öğretmen adaylarının öğretmenlik mesleğine yönelik tutumları ile cinsiyet arasındaki farka ilişkin t testi analiz sonuçları

\begin{tabular}{|c|c|c|c|c|c|c|}
\hline Cinsiyet & $\mathbf{N}$ & $\mathbf{X}$ & $\mathbf{S}$ & $\mathbf{S d}$ & $\mathbf{t}$ & $\mathbf{p}$ \\
\hline Erkek & 31 & 141,58 & 23,684 & 169 &,- 522 &, 605 \\
\hline Kadın & 139 & 143,95 & 18,699 & & & \\
\hline
\end{tabular}
${ }^{*} \boldsymbol{p}<.05$

Tablo 4 incelendiğinde öğretmen adaylarının tutum puanı ortalamaları, cinsiyetlere göre anlamlı bir farklılık göstermediği görülmektedir $[\mathrm{t}=-, 522, \mathrm{p}=, 605>0,05]$.

Aşağıda Tablo 5'te okul öncesi öğretmen adaylarının öğretmenlik mesleğine yönelik tutumları ile ikamet ettikleri yer arasındaki farka ilişkin $t$ testi analiz sonuçlarına ilişkin elde edilen bulgular verilmiştir.

Tablo 5 incelendiğinde öğretmen adaylarının tutum puanı ortalamaları, ikamet ettikleri yere göre anlamlı bir farklı- 
lık göstermediği görülmektedir [t=1,226, $\mathrm{p}=$,223>0,05].

Tablo 5. Okul öncesi öğretmen adaylarının öğretmenlik mesleğine yönelik tutumları ile ikamet ettikleri yer arasındaki farka ilişkin t testi analiz sonuçları

\begin{tabular}{|c|c|c|c|c|c|c|}
\hline ikamet Edilen Yer & N & X & S & Sd & t & p \\
\hline Kentsel Bölge & 41 & 146,41 & 16,206 & 169 & 1,226 &, 223 \\
\hline Kırsal Bölge & 129 & 142,60 & 20,589 & & & \\
\hline
\end{tabular}

\section{${ }^{*} p<.05$}

Aşağıda Tablo 6'da okul öncesi öğretmen adaylarının öğretmenlik mesleğine yönelik tutumları ile ailede başka öğretmen bulunma durumuna göre farka ilişkin $t$ testi analizi sonuçlarına ilişkin elde edilen bulgular verilmiştir.

Tablo 6. Okul öncesi öğretmen adaylarının öğretmenlik mesleğine yönelik tutumları ile ailede başka öğretmen bulunma durumuna göre farka ilişkin t testi analizi sonuçları

\begin{tabular}{|c|c|c|c|c|cc|}
\hline $\begin{array}{c}\text { Ailede Öğretmen } \\
\text { Bulunma Durumu }\end{array}$ & N & X & S & Sd & t & p \\
\hline Evet & 107 & 144,37 & 19,674 & 169 & 0,740 &, 461 \\
\hline Hayır & 63 & 142,06 & 19,666 & & & \\
\hline
\end{tabular}

Tablo 6 incelendiğinde öğretmen adaylarının tutum puanı ortalamaları, ailelerinde başka öğretmen bulunma durumuna göre istatistiksel olarak anlamlı bir farklılık göstermediği görülmektedir $[\mathrm{t}=0,740, \mathrm{p}=, 461>0,05]$.

Aşağıda Tablo 7'de okul öncesi öğretmen adaylarının öğretmenlik mesleğine yönelik tutumları ile mezun oldukları lise arasındaki farka ilişkin varyans analizi sonuçlarına ilişkin elde edilen bulgular verilmiştir.

Tablo 7. Okul öncesi öğretmen adaylarının öğretmenlik mesleğine yönelik tutumları ile mezun oldukları lise arasındaki farka ilişkin varyans analizi sonuçları

\begin{tabular}{|c|c|c|c|c|c|}
\hline Varyansın Kaynağı & $\begin{array}{c}\text { Kareler } \\
\text { Toplamı }\end{array}$ & Sd & $\begin{array}{c}\text { Kareler } \\
\text { Ortalaması }\end{array}$ & F & P \\
\hline Gruplar arası & 3032,432 & 4 & 758,108 & 2,011 &, 095 \\
\hline Gruplar içi & 62188,015 & 165 & 376,897 & & \\
\hline Toplam & 65220,447 & 169 & & & \\
\hline
\end{tabular}

Tablo 7’de görüldüğü gibi, öğretmen adaylarının öğretmenlik mesleğine ilişkin tutum puanı ortalamaları ile mezun oldukları lise arasında istatistiksel olarak anlamlı bir fark olmadığı görülmektedir [ $F=2,011, p=, 095>0,05]$.

Aşağıda Tablo 8'de okul öncesi öğretmen adaylarının öğretmenlik mesleğine yönelik tutumları ile sınıf düzeyleri arasındaki farka ilişkin varyans analizi sonuçlarına ilişkin elde edilen bulgular verilmiştir.

Tablo 8. Okul öncesi öğretmen adaylarının öğretmenlik mesleğine yönelik tutumları ile sınıf düzeyleri arasındaki farka ilişkin varyans analizi sonuçları

\begin{tabular}{|c|c|c|c|c|c|}
\hline Varyansın Kaynağı & $\begin{array}{c}\text { Kareler } \\
\text { Toplamı }\end{array}$ & Sd & $\begin{array}{c}\text { Kareler } \\
\text { Ortalaması }\end{array}$ & F & P \\
\hline Gruplar arası & 2644,690 & 3 & 881,563 & 2,339 &, 075 \\
\hline Gruplar içi & 62575,757 & 166 & 376,962 & & \\
\hline Toplam & 65220,447 & 169 & & & \\
\hline
\end{tabular}

${ }^{*} \boldsymbol{p}<.05$

Tablo 8'de görüldüğü gibi, öğretmen adaylarının öğretmenlik mesleğine ilişkin tutum puanı ortalamaları ile sınıf düzeyleri arasında istatistiksel olarak anlamlı bir fark olmadığı görülmektedir [ $\mathrm{F}=2,339, \mathrm{p}=, 075>0,05]$.
Aşağıda Tablo 9'da okul öncesi öğretmen adaylarının öğretmenlik mesleğine yönelik tutumları ile alan tercih sıraları arasındaki farka ilişkin varyans analizi sonuçlarına ilişkin elde edilen bulgular verilmiştir.

Tablo 9 . Okul Öncesi Öğretmen Adaylarının Öğretmenlik Mesleğine Yönelik Tutumları ile Alan Tercih Sıraları Arasındaki Farka İlişkin Varyans Analizi Sonuçları

\begin{tabular}{|c|c|c|c|c|c|}
\hline $\begin{array}{c}\text { Varyansın } \\
\text { Kaynağı }\end{array}$ & $\begin{array}{c}\text { Kareler } \\
\text { Toplamı }\end{array}$ & Sd & $\begin{array}{c}\text { Kareler } \\
\text { Ortalaması }\end{array}$ & $\mathbf{F}$ & $\mathbf{P}$ \\
\hline Gruplar arası & 1375,994 & 4 & 343,998 &, 889 &, 472 \\
\hline Gruplar içi & 63844,453 & 165 & 386,936 & & \\
\hline Toplam & 65220,447 & 169 & & & \\
\hline
\end{tabular}

${ }^{*} p<.05$

Tablo 9'da görüldüğü gibi, öğretmen adaylarının öğretmenlik mesleğine ilişkin tutum puanı ortalamaları ile alan tercih sıraları arasında istatistiksel olarak anlamlı bir fark olmadığı görülmektedir [ $\mathrm{F}=, 889, \mathrm{p}=, 472>0,05]$.

Aşağıda tablo 10'da okul öncesi öğretmen adaylarının öğretmenlik mesleğine yönelik tutumları ile alan tercihlerine etki eden faktörler arasındaki farka ilişkin varyans analizi sonuçlarına dair elde edilen bulgular verilmiştir.

Tablo 10. Okul öncesi öğretmen adaylarının öğretmenlik mesleğine yönelik tutumları ile alan tercihlerine etki eden faktörler arasındaki farka ilişkin varyans analizi sonuçları

\begin{tabular}{|c|c|c|c|c|c|c|}
\hline $\begin{array}{c}\text { Varyansın } \\
\text { Kaynağı }\end{array}$ & $\begin{array}{c}\text { Kareler } \\
\text { Toplamı }\end{array}$ & Sd & $\begin{array}{c}\text { Kareler } \\
\text { Ortalaması }\end{array}$ & F & P & $\begin{array}{c}\text { Anlamlı } \\
\text { Fark }\end{array}$ \\
\hline Gruplar arası & 6590,054 & 4 & 1647,513 & 4,636 &, 001 & \\
\hline Gruplar içi & 58630,393 & 165 & 355,336 & & & \\
\hline Toplam & 65220,447 & 169 & & & & \\
\hline
\end{tabular}

$* p<.05$

Tablo 10'da görüldüğü gibi, öğretmen adaylarının öğretmenlik mesleğine ilişkin tutum puanı ortalamaları ile alan tercihlerine etki eden faktörler arasında anlamlı bir fark olduğu görülmektedir [ $F=4,636, p=, 001<0,05]$. Farkın hangi gruplardan kaynaklandığını bulmak amacıyla LSD testi yapılmıştır. Bu sonuçlara göre; Alana İlgisi Olduğu için tercihlerini yapan öğretmen adayları $(150,78)$ grubu ile Ailesi İstediği için $(131,78)$, Atanma İhtimali Yüksek Olduğu için (139,3), Diğer Nedenlerden dolayı (134) grupları arasında istatistiksel olarak anlamlı bir farklılık vardır. Ayrıca Meslek Sahibi Olmak için tercihini yapan öğretmen adayları $(145,23)$ grubu ile diğer nedenlerden dolayı tercihlerini yapan öğretmen adayları (134) grubu arasında istatistiksel olarak anlamlı bir farklılık olduğu bulunmuştur.

Aşağıda Tablo 11'de okul öncesi öğretmen adaylarının öğretmenlik mesleğine yönelik tutumları ile alan tercih seçimlerine etki eden kişiler arasındaki farka ilişkin varyans analizi sonuçlarına dair elde edilen bulgular verilmiştir.

Tablo 11 . Okul öncesi öğretmen adaylarının öğretmenlik mesleğine yönelik tutumları ile alan tercih seçimlerine etki eden kişiler arasındaki farka ilişkin varyans analizi sonuçları

\begin{tabular}{|c|c|c|c|c|c|c|}
\hline $\begin{array}{c}\text { Varyansın } \\
\text { Kaynağı }\end{array}$ & $\begin{array}{c}\text { Kareler } \\
\text { Toplamı }\end{array}$ & Sd & $\begin{array}{c}\text { Kareler } \\
\text { Ortalaması }\end{array}$ & F & P & $\begin{array}{c}\text { Anlamlı } \\
\text { Fark }\end{array}$ \\
\hline Gruplar arası & 5937,263 & 3 & 1979,088 & 5,542 &, 001 & \\
\hline Gruplar içi & 59283,184 & 166 & 357,128 & & & \\
\hline Toplam & 65220,447 & 169 & & & & \\
\hline
\end{tabular}




\section{${ }^{*} p<.05$}

Tablo 11'de görüldüğü gibi, öğretmen adaylarının öğretmenlik mesleğine ilişkin tutum puanı ortalamaları ile alan tercih seçimlerine etki eden kişiler arasında istatistiksel olarak anlamlı bir fark olduğu görülmektedir $[\mathrm{F}=5,542$, $\mathrm{p}=, 001<0,05]$. Farkın hangi gruplardan kaynaklandığ ${ }^{-}$ nı bulmak amacıyla LSD testi yapılmıştır. Bu sonuçlara göre, alan tercihlerini Ailesinin etkisiyle yapan öğretmen adayları $(131,17)$ grubu ile alan tercihlerini Kendi İsteğiyle yapan öğretmen adayları $(146,8)$ ve Rehber Öğretmeninin etkisiyle gelen öğretmen adayları $(144,94)$ grupları arasında istatistiksel olarak anlamlı bir farklılık olduğu bulunmuştur.

Aşağıda Tablo 12'de okul öncesi öğretmen adaylarının öğretmenlik mesleğine yönelik tutumları ile öğrenim gördükleri alandan memnuniyet durumları arasındaki farka ilişkin varyans analizi sonuçlarına dair elde edilen bulgular verilmiştir.

Tablo 12. Okul öncesi öğretmen adaylarının öğretmenlik mesleğine yönelik tutumları ile öğrenim gördükleri alandan memnuniyet durumları arasındaki farka ilişkin varyans analizi sonuçları

\begin{tabular}{|c|c|c|c|c|c|c|}
\hline $\begin{array}{c}\text { Varyansın } \\
\text { Kaynağı }\end{array}$ & $\begin{array}{l}\text { Kareler } \\
\text { Toplamı }\end{array}$ & Sd & $\begin{array}{c}\text { Kareler } \\
\text { Ortalaması }\end{array}$ & $\mathbf{F}$ & $\mathbf{P}$ & $\begin{array}{c}\text { Anlamlı } \\
\text { Fark }\end{array}$ \\
\hline Gruplar arası & 15404,593 & 2 & 7702,297 & 25,821 & ,000 & \\
\hline Gruplar içi & 49815,854 & 167 & 298,299 & & & \\
\hline Toplam & 65220,447 & 169 & & & & \\
\hline
\end{tabular}

Tablo 12'de görüldüğü gibi, öğretmen adaylarının öğretmenlik mesleğine ilişkin tutum puanı ortalamaları ile öğrenim gördükleri alandan memnuniyet durumları arasında istatistiksel olarak anlamlı bir fark olduğu görülmektedir [ $\mathrm{F}=25,821, \mathrm{p}=, 000<0,05]$. Farkın hangi gruplardan kaynaklandığını bulmak amacıyla LSD testi yapılmıştır. Bu sonuçlara göre, öğrenim gördükleri alandan Memnun Olan öğretmen adayları $(148,34)$ grubu ile Kısmen Memnun olan öğretmen adayları $(133,39)$ ve Memnun Olmayan öğretmen adayları $(108,14)$ grupları arasında istatistiksel olarak anlamlı bir farklılık olduğu sonucu bulunmuştur. Ayrıca öğrenim gördükleri alandan Kısmen Memnun olan öğretmen adayları $(133,39)$ grubu ile Memnun Olmayan öğretmen adayları $(108,14)$ arasında anlamlı bir farklılık olduğu sonucu bulunmuştur.

\section{TARTIŞMA}

Okul öncesi öğretmen adaylarının, öğretmenlik mesleğine yönelik tutum puanlarının yüksek olduğu sonucuna ulaşılmıştır. Bu durum öğretmen adaylarının, öğretmenlik mesleğine yönelik olumlu duygu ve düşüncelere sahip olduğu söylenebilir. Bu sonuç Aynal (2013) tarafindan yapılan okul öncesi öğretmen adaylarının öğretmenlik mesleğine yönelik tutumlarını belirlemeye yönelik yaptığı çalışma ile Erkan vd. (2002) tarafından yapılan okul öncesi öğretmenliği öğrencilerine ait Türkiye profil araştırması çalışmasının sonucuyla paralellik göstermektedir.

Okul öncesi öğretmen adaylarının alan tercihlerini ilk 5 sırada yaptıkları ve okul öncesi öğretmenliği alanına ken- di istekleri ile tercih yaptıkları sonucuna ulaşılmıştır. Bu sonuç bağlamında, okul öncesi öğretmenliği mesleğinin son yıllarda popüler bir meslek haline geldiği ve bu alana dair ilgi duyulduğu düşünülebilir. Bu sonuç, Erkan ve arkadaşları (2002) tarafından yapılan çalışmanın sonucuyla paralellik göstermektedir.

Okul öncesi öğretmen adaylarının babalarının meslekleri incelendiğinde en yüksek oranın işçi ve memur olduğu sonucuna ulaşılmıștır. Bu sonuç, 1986 yılında yayınlanan Türkiye İstatistik Bülteni'nde yükseköğrenim gören gençlerin ailelerinin büyük çoğunluğu memur, işçi gibi orta ekonomik güce sahip ailelerdir sonucuyla paralellik göstermektedir (TİK, 1986; akt: Karasar vd.,1999) .

Okul öncesi öğretmen adaylarının mesleğini tercih etme sebebi olarak alana ilgisinden dolayı seçtiği sonucuna ulaşılmıştır. Bu sonuç, Türküm vd. (2004) tarafından yapılan çalışmanın öğrencilerin okudukları bölümü seçmelerinde meslek sahibi olma ve iş bulma avantajları gibi etmenlerin etkili olduğu sonuçlarıyla paralellik göstermemektedir. Bu sonuç bağlamında, okul öncesi öğretmenliği mesleğinin tercih edilme sebebinin son ylllarda popüler bir meslek haline gelmesi ve öğretmen adaylarının bu alana dair ilgi duyulması olarak düşünülebilir (Erkan vd., 2002) .

Okul öncesi öğretmen adaylarının öğretmenlik mesleğine yönelik tutumları, ailelerinde öğretmen bulunma durumuna göre anlamlı bir farklılık göstermemektedir. Öğretmen adayları genel olarak öğretmenlik mesleğine yönelik ailelerinde öğretmen bulunma durumuna göre aynı tutum içerisinde olduğu düşünülebilir. Daha önce benzer yapılmış çalışmalarda da okul öncesi öğretmen adaylarının ailelerinde öğretmen bulunma durumu değişkenine göre öğretmenlik mesleğine yönelik tutumlarında anlamlı fark bulunmadığı görülmektedir (Kutlu, Gökdere, Çakır, 2015; Kol, 2015) .

Öğretmen adaylarının öğretmenlik mesleğine yönelik tutumları, cinsiyet değişkenine göre anlamlı bir farklılık göstermemektedir. Öğretmen adayları genel olarak öğretmenlik mesleğine yönelik kız ve erkek olarak aynı tutum içerisinde olduğu düşünülebilir. Daha önce benzer yapılmış çalışmalarda da cinsiyet değişkenine göre öğretmen adaylarının öğretmenlik mesleğine yönelik tutumlarında anlamlı fark bulunmadığı görülmektedir (Açışlı ve Kolomuç, 2012; Bademcioğlu, Karataş, Alcı, 2014;Balc1, 2017; Bulut, 2009; Bulut ve Doğar, 2006; Can, 2010; Tuncer ve Dikmen, 2018; Ekici, 2014; Keskin, 2017; Özder vd., 2010; Semerci ve Semerci, 2004; Tüfekci ve Kocabatmaz, 2015) . Bu çalışmanın sonucu; Alkan (2018), Atmaca (2015), Baykara Pehlivan (2008), Çapri ve Çelikkaleli (2008), Şahin ve Şahin (2017), Tekerek ve Polat (2011), Uyanık (2017) yapmış oldukları çalışmanın sonucuyla örtüşmemektedir.

Öğretmen adaylarının öğretmenlik mesleğine yönelik tutumları, alan tercih sıraları değişkenine göre anlamlı bir farklılık göstermemektedir. Öğretmen adayları genel olarak tercih sıralarına göre aynı tutum içerisinde olduğu 
düşünülebilir. Daha önce benzer yapılmış çalışmalarda da alan tercihlerine göre öğretmen adaylarının öğretmenlik mesleğine yönelik tutumlarında anlamlı fark bulunmadığ görülmektedir (Aydın ve Sağlam, 2012, Baykara Pehlivan, 2008) . Bu çalışmanın sonucu Uyanık (2017) yapmış olduğu çalışmanın sonucuyla örtüşmemektedir.

Öğretmen adaylarının öğretmenlik mesleğine yönelik tutumları, alan tercihlerine etki eden faktörlere göre anlamlı bir farklılık göstermektedir. Daha önce benzer yapılmıș çalışmalarda da alan tercihlerine etki eden faktörlere göre öğretmen adaylarının öğretmenlik mesleğine yönelik tutumlarında anlamlı fark bulunduğu görülmektedir (Aydın ve Sağlam, 2012; Bozdoğan, Aydın ve Yıldırım, 2007) .

Öğretmen adaylarının öğretmenlik mesleğine yönelik tutumları, sınıf düzeylerine göre anlamlı bir farklılık göstermemektedir. Öğretmen adayları genel olarak sınıf düzeylerine göre aynı tutum içerisinde olduğu düşünülebilir. Daha önce benzer yapılmış çalışmalarda da sınıf düzeylerine göre öğretmen adaylarının öğretmenlik mesleğine yönelik tutumlarında anlamlı fark bulunmadığı görülmektedir (Alkan, 2018; Bulut ve Doğar, 2006; Tuncer ve Dikmen, 2018; Özder vd., 2010). Bu çalışmanın sonucu; Atmaca (2015), Şahin ve Şahin (2017), Uyanık (2017) yapmış oldukları çalışmanın sonucuyla örtüşmemektedir.

Öğretmen adaylarının öğretmenlik mesleğine yönelik tutumları, mezun olunan lise türlerine göre anlamlı bir farklılık göstermemektedir. Bu sonuç bağlamında, öğretmen adayları genel olarak mezun oldukları lise türüne göre aynı tutum içerisinde olduğu düşünülebilir. Daha önce benzer yapılmış çalışmalarda da mezun olunan lise türlerine göre öğretmen adaylarının öğretmenlik mesleğine yönelik tutumlarında anlamlı fark bulunmadığı görülmektedir (Atmaca, 2015; Aydın ve Sağlam, 2012; Kutlu vd., 2015; Tüfekci ve Kocabatmaz, 2015;) .

\section{SONUÇLAR}

Çalışmada elde edilen bulgular;

- Öğretmen adaylarının, öğretmenlik mesleğine yönelik tutumlarının çok yüksek olduğu sonucunu ortaya koymuştur.

- Öğretmen mesleğine ilişkin tutum puanları; cinsiyet, yaşadıkları yer, sınıf düzeyleri, tercih sıraları, mezun oldukları lise türü ve ailelerinde öğretmen bulunma durumuna göre anlamlı bir farklılık göstermediği sonucunu ortaya koymuştur.

- Öğretmen mesleğine ilişkin tutum puanları; tercihlere etki eden faktörler, tercihlere etki eden kişiler, alandan memnuniyet durumuna göre anlamlı bir farklılık gösterdiği sonucunu ortaya koymuştur. Bu farklılıkların; öğretmen adaylarının alana ilgisinin olması, alan tercihlerine kendi isteğiyle gelmesi ve öğrenim gördükleri alandan memnun olmalarından kaynaklandığı sonucuna ulaşılmıştır.
Bu araștırmanın sonucunda; okul öncesi öğretmen adaylarının öğretmenlik mesleğine ilişkin tutum puanlarının çok yüksek olmasının, meslek yaşantılarında gerçekleştirecekleri okul öncesi eğitimine dair olumlu katkılar sağlayacağı düşünülmektedir.

\section{6. ÖNERILER}

- Bu araştırma sadece Mersin Üniversitesi Eğitim Fakültesi'nde yapılmıştır. Türkiye'deki diğer üniversitelerin eğitim fakültelerinde de öğretmenlik mesleğine ilişkin tutumların belirlenmesine yönelik çalışmalar yapilabilir.

- Bu araştırma sadece Mersin Üniversitesi Eğitim Fakültesi'nde eğitim görmekte olan okul öncesi öğretmen adaylarına yönelik yapılmıștır. Türkiye'deki diğer üniversitelerin eğitim fakültelerinde diğer alanlarda eğitim görmekte olan öğretmen adaylarıyla öğretmenlik mesleğine ilişkin tutumların belirlenmesine yönelik çalışmalar yapılabilir.

- Bu çalışmada 14 soru ile öğretmen adaylarının özellikleri belirlenmeye çalışılmıştır. Demografik, sosyo-ekonomik değişkenlerin arttırılmasıyla çalışma tekrarlanabilir.

- Gelişmiş ülkeler öğretmenlik mesleğinin tercih edilen ve istenilen meslek gruplarında yer alması için neler yapılabileceğine ilişkin araştırmalarına devam etmektedirler (Diamond, 2001). Bu bağlamda; Türkiye'nin de gelişmekte olan ülkeler kategorisinde olduğunu düşünüldüğünde; öğretmenlik mesleğinin tercih edilen ve elit meslek gruplarında yer alması için neler yapılabileceğine ilişkin çalışmalar yapılabilir.

\section{KAYNAKÇA}

Açışı, S., \& Kolomuç, A. (2012). Sınıf öğretmeni adaylarının öğretmenlik mesleğine yönelik tutumlarının incelenmesi. Eğitim ve Öğretim Araştırmaları Dergisi, 1(2), 266-271.

Adıgüzel, A. (1998). Öğretmen yetiştirme meslek formasyonu öğretiminin öğretmen davranışlarına yansıması. Yayınlanmamış Yüksek Lisans Tezi, Harran Üniversitesi, Şanlı Urfa.

Akyol, A. K., \& Çiftçibaşı, H. K. (2005). Okul öncesi öğretmen adaylarının empatik beceri düzeylerinin belirlenmesi. Eğitim Araştırmaları Dergisi, 21, 13-23.

Alkan, M. F. (2018). Öğretmen Adaylarının Öğretmenlik Mesleğine Yönelik Tutumlarının Incelenmesi. SDU International Journal of Educational Studies, 5(1), 13-21.

Ambusaidi, A., \& Al-Farei, K. (2017). Investigating omani science teachers' attitudes towards teaching science: the role of gender and teaching experiences. International Journal of Science and Mathematics Education, 15(1), 71-88.

Argun, Y., \& İkiz, E. (2003). Okul Öncesi Öğretmenliği Programının Öğrencilerin Mesleki Tutum ve Algılarına Etkilerinin Incelenmesi. OMEP Dünya Konsey Toplantısı ve Konferansı, 8-11.

Atmaca, H. (2015). Yabancı Dil Öğretmen Adaylarının Öğretmenlik Mesleğine İlişkin Tutumlarının İncelenmesi. Uludağ Üniversitesi Eğitim Fakültesi Dergisi, 28(1. ÖzelSayı), 401412. 
Aşkar, P., \& Erden, M. (1987). Öğretmenlik mesleğine yönelik tutum ölçeği. Çağdaş Eğitim, 121(12), 8-11.

Aydın, R., \& Sağlam, G. (2012). Öğretmen adaylarının öğretmenlik mesleğine yönelik tutumlarının belirlenmesi (Mehmet Akif Ersoy Üniversitesi örneği). Türk Eğitim Bilimleri Dergisi, 10(2), 257-294.

Aynal, Ş. Ö. (2013). Okul öncesi öğretmen adaylarının öğretmenlik mesleğine ilişkin tutumları. The Journal of Academic Social Science Studies, 6(5), 1037-1048.

Bademcioğlu, M., Karataş, H. ve Alcı, B. (2014). The investigation of teacher candidates' attitudes towards teaching profession (Öğretmen adaylarının öğretmenlik mesleğine ilişkin tutumlarına yönelik inceleme. Educational Research Association - The Interna-tional Journal of Educational Researchers, 5(2), 16-29.

Balcı, S. (2017). Öğretmen Adaylarının Öğretmenlik Mesleğine Yönelik Tutumlarının İncelenmesi. In ICPESS (International Congress on Politic, Economic and Social Studies) (No. 3).

Bozdoğan, A. E., Aydın, D., \& Yıldırım, K. (2007). Öğretmen adaylarının öğretmenlik mesleğine ilişkin tutumları. Ahi Evran Üniversitesi Kırşehir Eğitim Fakültesi Dergisi, 8(1), 209-222

Bulut, H. ve Doğar, Ç.(2006). Öğretmen adaylarının öğretmenlik mesleğine karşı tutumlarının incelenmesi. Erzincan Eğitim Fakültesi Dergisi, 8(1), 13-27.

Can, Ş. (2010). Tezsiz yüksek lisans öğrencilerinin öğretmenlik mesleğine yönelik tutumları. Muğla Üniversitesi Sosyal Bilimler Enstitüsü Dergisi 24, 13-28.

Çapri, B., \& Çelikkaleli, Ö. (2008). Investigation of pre-service teachers' attitudes towards teaching and professional self-efficacy beliefs according to their gender, programs, and faculties. Inönü Üniversitesi Eğitim Fakültesi Dergisi, 9(15), 33-53.

Çetin, Ö. (2017). İslami İlimler/ilahiyat Fakültesi Öğrencilerinin Öğretmenlik Mesleğine Yönelik Tutumlarının İncelenmesi (Uşak Üniversitesi Örneği). Hitit Üniversitesi Illahiyat Fakültesi Dergisi, 16(32), 411-432.

Erbay, E. (2008). Okul öncesi eğitim alan ve almayan ilköğretim birinci sınıf öğrencilerinin sosyal becerilere sahip olma düzeyleri (Doctoral dissertation, Pamukkale Üniversitesi).

Erdem, A. R., Gezer, K., \& Çokadar, H. (2005). Ortaöğretim fen-matematik ve sosyal alanlar öğretmenliği tezsiz yüksek lisans öğrencilerinin öğretmenlik mesleğine ilişkin tutumlarI. XIV. Ulusal Eğitim Bilimleri Kongresi, 1, 471-477.

Erkan, S., Tuğrul, B., Üstün, E., Akman, B., \& Şendoğdu, M. (2002). Okulöncesi öğretmenliği öğrencilerine ait türkiye profil araştıması. Hacettepe Üniversitesi Eğitim Fakültesi Dergisi, 23(23).

Esaspehlivan, M. (2006). Okul öncesi eğitim kurumuna gitmiş ve gitmemiş 78 ve 68 aylık çocukların okula hazır bulunuşluklarının karşılaştırılması. Yayınlanmamış yüksek lisans tezi, Marmara Üniversitesi Eğitim Bilimleri Enstitüsü, İstanbul.

Garmon, M. A. (2004). Changing preservice teachers' attitudes/ beliefs about diversity: What are the critical factors?. Journal of Teacher Education, 55(3), 201-213.

Gürbüz, H., ve Kışoğlu, M. (2007). Tezsiz yüksek lisans programına devam eden fenedebiyat ve eğitim fakültesi öğrencilerinin öğretmenlik mesleğine yönelik tutumları (Atatürk Üniversitesi örneği). Erzincan Eğitim Fakültesi Dergisi, 9(2), 71-83.
Johnson, G. M., \& Howell, A. J. (2005). Attitude towardn instructional technology following required versus optional WebCTusage. Journal Of Technology And Teacher Education, (4), 643.

Karakaya, I. (2011) Bilimsel araştırma yöntemleri (Editör: Abdurrahman Tanrıöğen, Bilimsel araştırma yöntemleri içinde, s:55-84), Ankara: Anı Yayıncılık.

Karasar, N. (2012). Bilimsel Aratrma Yntemi (25. Bask). Ankara: Nobel Yayn Dalm.

Karasar, N., Hakan, A., Can, G., Özdeş, K., Sözer, E., Gültekin, M., ... \& Şenel, A. (1999). Anadolu Üniversitesi Öğrencilerinin Sosyo-Kültürel ve Sosyo-Ekonomik Özellikleri ile Beklenti ve Sorunları. Eskişehir: Anadolu Üniversitesi Yayını.

Keskin, Y. (2017). Coğrafya öğretmen adaylarının öğretmenlik mesleğine yönelik tutum ve kaygı düzeyleri (Erzurum Örneği). e-Kafkas Eğitim Araştırmaları Dergisi, 4(2), 43-57.

Krecic, M. J., \& Grmek, M. I. (2005). The reasons students choose teaching professions. Educational Studies, 31(3), 265-274.

Kutlu, N., Gökdere, M., \& Çakır, R. (2015). Öğretmen adaylarının akademik erteleme davranışı ile öğretmenlik mesleğine ilişkin tutumlarının karşılaştırmalı incelenmesi. Kastamonu Eğitim Dergisi, 23(3), 1311-1330.

Oktay, A. (2000). Yaşamın sihirli yılları: Okul öncesi dönem. Epsilon.

Oktay, A. (2005). Erken Çocuklukta Gelişim ve Eğitimde Yeni Yaklaşımlar (Yayıma Hazırlayan Doç. Dr. Müzeyyen Sevinç), 21. Yüzyıla Girerken Dünyada Yaşanan Değişimler ve Erken Çocukluk Eğitimi, Morpa Kültür Yayınları, İstanbul, 18-30.

Pehlivan, D. (2006). Okul öncesi eğitim alan ve almayan öğrencilerin ilk okuma yazmaya geçiş sürecinin, öğretmen ve öğrenci görüşleri doğrultusunda değerlendirilmesi. Yayınlanmamış Yüksek Lisans Tezi. Çukurova Üniversitesi Sosyal Bilimler Enstitüsü Illköğretim Anabilim Dalı, Adana.

Pehlivan, K. B. (2008). Sınıf öğretmeni adaylarının sosyo-kültürel özellikleri ve öğretmenlik mesleğine yönelik tutumları üzerine bir çalışma. Mersin Üniversitesi Eğitim Fakültesi Dergisi, 4(2).

Poyraz, H., \& Dere, H. (2001). Okul öncesi eğitimin ilke ve yöntemleri. Ankara: Anı Yayıncılık.

Razon, N. (1987). Okulöncesi çocukta sık rastlanan uyum ve davranış sorunlarından bazıları ve anaokulunda çözüm önerileri. Proceedings of the Ya-Pa Okul Öncesi Eğitimi ve Yaygınlaştırılması Semineri, Turkey, 5, 73-85.

Seferoğlu, S. S. (2004). Öğretmen adaylarının öğretmenliğe yönelik tutumları. XII. Ulusal Eğitim Bilimleri Kongresi Bildirileri. Ankara, 413-425.

Shippen, M. E., Crites, S. A., Houchins, D. E., Ramsey, M. L., \& Simon, M. (2005). Preservice teachers' perceptions of including students with disabilities. Teacher Education and Special Education: The Journal of the Teacher Education Division of the Council for Exceptional Children, 28(2), 92-99.

Şahin, C., \& Şahin, S. (2017). Öğretmen Adaylarının Öğretmenlik Mesleğine Karşı Tutumları, Öz-Yeterlik İnançları ve Öğrenciyi Tanıma Düzeyleri. Türk Eğitim Bilimleri Dergisi, 15(2), 224-238.

Tekerek, M., \& Polat, S. (2011). Öğretmen adaylarının öğretmenlik mesleğine ilişkin tutumları. 5th International Computer \& Instructional Technologies Sempozyumu'nda sunulmuş bildiri. Fırat Üniversitesi, Elazığ. 
Toluç, Z. (2008). İlköğretim birinci sınıf öğretmenlerinin görüşlerine göre okul öncesi eğitim alan ve almayan öğrencilerin gelişim becerilerinin karşılaştırılması. Yayınlanmamış Yüksek Lisans Tezi, Beykent Üniversitesi Sosyal Bilimler Enstitüsü, İstanbul.

Tuncer, M., \& Dikmen, M. (2018). Öğretmen adaylarının bilgi okuryazarlık öz-yeterlikleri ve mesleğe yönelik tutumları. Akademik Bakış Uluslararası Hakemli Sosyal Bilimler Dergisi, (66), 310-325.

Tüfekci, A., \& Kocabatmaz, H. (2015). Bilgisayar öğretmeni adaylarının öğretmenlik mesleğine yönelik tutumlarının değerlendirilmesi. Gazi Üniversitesi Gazi Eğitim Fakültesi Dergisi, 35(3).

Türküm, A. S., Kızıltaş, A., Yemenici, B. ve Bıyık, N., (2004). Anadolu Üniversitesi Öğrencilerinin Sosyo-Demografik Özellikleri, Sorunları ve Üniversiteye Illişkin Görüşleri. Eskişehir:Anadolu Üniversitesi Yayınları; No:1597, 2004 Sayfa:8.

Uyanık, G. (2017). Sınıf öğretmeni adaylarının öğretmenlik mesleğine yönelik tutumlarının çeşitli değişkenlere göre incelenmesi: Boylamsal bir araştırma. Uluslararası Türk Eğitim Bilimleri Dergisi, 2017(8), 185-195.

Yaylak, E. (2019). Sosyal Bilgiler Öğretmen Adaylarının Öğretmenlik Mesleğine Yönelik Tutumlarının İncelenmesi. Uluslararası Sosyal Bilgilerde Yeni Yaklaşımlar Dergisi (IJONASS), 3(1), 25-40.

Yeşil, D. (2008). Okul öncesi eğitim almış ve almamış öğrencilerin okula uyumlarının karşılaştııılması. Yayımlanmamış Yüksek Lisans Tezi, Yeditepe Üniversitesi Sosyal Bilimler Enstitüsü, İstanbul. 